\title{
Застосування високочастотного електрохірургічного апарата “ERBE ICC 200" для лікування пацієнтів з поєднаною патологією анального каналу і прямої кишки
}

\author{
М. П. Захараш ${ }^{1}$, В. В. Балицький ${ }^{2,3}$, О. Г. Курик ${ }^{4}$
}

${ }^{1}$ Національний медичний університет імені О. О. Богомольця, м. Київ, ${ }^{2}$ Вінницький національний медичний університет імені М. І. Пирогова, ${ }^{3}$ Хмельницька обласна лікарня,

${ }^{4}$ Науково-практичний центр профілактичної та клінічної медицини Державного управління справами, м. Київ

\section{Application of high-frequency electrosurgical apparatus "ERBE ICC 200" for treatment of patients, suffering coexistant pathology of anal channel and rectum}

\author{
M. P. Zakharash ${ }^{1}$, V. V. Balytskyy ${ }^{2,3}$, O. G. Kuryk ${ }^{4}$ \\ ${ }^{1}$ Bogomolets National Medical University, Kyiv, \\ ${ }^{2}$ M. I. Pyrogov Vinnytsya National Medical University, \\ ${ }^{3}$ Khmelnytskyi Regional Hospital, \\ ${ }^{4}$ Scientific-Practical Centre of Prophylactic and Clinical Medicine, Kyiv
}

\section{Реферат}

Мета. Покращення результатів хірургічного лікування пацієнтів з поєднаною патологією (ПП) анального каналу і прямої кишки шляхом використання апарата високочастотної електрохірургії (BЧEX) "ERBE ICC 200".

Матеріали і методи. Проаналізовані результати лікування 164 пацієнтів з ПП анального каналу і прямої кишки з використанням апарата ВЧEX “ЕRBE ICC 200”.

Результати. Встановлено, що при використанні апарата BЧEX “ERBE ICC 200” зменшуються тривалість операції - до (20 \pm 5$)$ хв, об'єм крововтрати - до (15 \pm 5$)$ мл, потреба в наркотичних аналгетиках - до $(2 \pm 1)$ мл, тривалість стаціо-

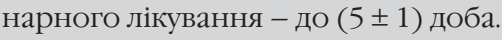

Висновки. Застосування апарата ВЧEX “ERBE ICC 200” приводить до скорочення тривалості операції, зменшення крововтрати під час операції, а також інтенсивності болю в післяопераційному періоді. Використання даної хірургічної технології забезпечує незначну глибину некрозу тканин - $(0,286 \pm 0,15)$ мм та косметичність операції.

Ключові слова: поєднана патологія; анальний канал; пряма кишка; апарат високочастотної електрохірургіï "ERBE ICC $200 "$ ".

\section{Abstract}

Objective. Improvement of the surgical treatment results in patients, suffering combined pathology of anal channel and rectum, using apparatus of a high-frequency electrosurgery (HFES) "ERBE ICC 200".

Materials and methods. Results of treatment of 164 patients, suffering combined pathology of anal channel and rectum, using apparatus HFES "ERBE ICC 200”.

Results. There was established, that while application of HFES "ERBE ICC 200" apparatus the operation duration reduces to $(20 \pm 5) \mathrm{min}$, the blood loss volume - to $(15 \pm 5) \mathrm{ml}$, the need for narcotic analgetics - to $(2 \pm 1) \mathrm{ml}$, the stationary treatment duration - to $(5 \pm 1)$ days.

Conclusion. The apparatus HFES "ERBE ICC 200" application brought to shortening of the operation duration, the intraoperative blood loss reduction, and postoperative pain intensity as well. Application of such surgical technology guarantees nonsignificant depth of the tissues necrosis achievement $-(0.286 \pm 0.15) \mathrm{mm}$ and the operation cosmetics.

Keywords: combined pathology; rectum; apparatus of a high-frequency electrosurgery "ERBE ICC 200".

Серед проктологічних захворювань частка ПП анального каналу і прямої кишки становить 35 - 57\% і стрімко зростає $[1,2]$.

Найчастіше серед ПП зустрічається комбінація геморою з анальною тріщиною, норицями прямої кишки, анальними поліпами, новоутвореннями [3], рідше поєднання геморою II-IV стадій з гострим парапроктитом, гострокінцевими кондиломами, параректальними кістами, гіпертрофованими анальними сосочками, ворсинчастими пухлинами прямої кишки [4]. Після хірургічного лікування пацієнтів з ПП анального каналу і прямої кишки нерідко виникають стриктури анального каналу, недостатність анального сфінктера, рубцеві деформації промежини і параректальних ділянок [5, 6]. Тому є актуальною необхідність розробляти та впроваджувати нові високотехнологічні методи лікування ПП анального каналу і прямої кишки, направлені на зменшення операційної травми та зниження інтенсивності післяопераційного больового синдрому, зменшення тривалості операції та крововтрати під час ії проведен- 
ня, скорочення термінів загоєння післяопераційних ран і реабілітації пацієнтів.

Мета дослідження: покращення результатів хірургічного лікування пацієнтів з ПП анального каналу і прямої кишки шляхом використання апарата BЧEX "ERBE ICC $200 "$.

\section{матеріали і методи дослідження}

3 березня 2008 по серпень 2017 р. у відділенні проктології Хмельницької обласної лікарні прооперовано 164 пацієнти з ПП анального каналу і прямої кишки з використанням апарата ВЧEX “ERBE ICC 200” (досліджувана група). Пацієнтів чоловічої статі було 101 (62\%), жіночої - 63 (38\%). Вік пацієнтів коливався від 20 до 76 років.

У досліджувану групу включили 52 пацієнти, яким виконували оперативні втручання з використанням апарата BЧEX "ERBE ICC 200" виробництва німецької фірми ERBE Elektromedizin GmbH. В основі дії цього апарата 3 вихідною частотою 330 кГц і номінальною потужністю 50 - 80 Вт/200 - 500 Ом є система автоматичного регулювання потужності, яка розпізнає низькоомні навантаження, регулюючи дію високочастотного генератора, завдяки чому забезпечується якість розрізу тканин та необхідна інтенсивність високочастотної напруги.

Контрольну групу склали 112 пацієнтів з ПП анального каналу і прямої кишки, прооперованих традиційно без використання апарата ВЧЕХ. Всі оперативні втручання виконані під спинномозковою анестезією.

Всім пацієнтам перед операцією проведено огляд перианальної і параректальних ділянок, виконано пальцеве дослідження анального каналу і прямої кишки, ректороманоскопію, а також з метою дообстеження і виключення патології ободової кишки 68 (41,5\%) пацієнтам у віці старше 45 років виконано ірігоскопію або фіброколоноскопію.

Після оперативних втручань методом високочастотної хірургії проводили морфологічне дослідження тканин з метою вивчення глибини їх некрозу, а для порівняння використовували операційний матеріал після застосування звичайного металевого скальпеля.

Операційний матеріал фіксували у $10 \%$ розчині нейтрального формаліну. Далі використовували гістопроцесор карусельного типу STP-120, для заливки парафінових блоків - станцію ЕC-350, для різки парафінових блоків - ротаційний мікротом серії НM - 340Е, для забарвлення гістологічних препаратів - автомат RobotStainer HMS-740 (всі апарати фірми Carl Zeiss MICROM International $\mathrm{GmbH})$. Препарати забарвлювали гематоксиліном та еозином. Використовували мікроскоп Axioskop 40 з фотокамерою Axio Cam MRc5 (Karl Zeiss).

\section{Результати}

У 128 (78\%) пацієнтів виявлено два, у 34 (21\%) - три, у 2 (1\%) - чотири захворювання анального каналу та прямої кишки.

Найчастіше зустрічали такі варіанти ПП анального каналу і прямої кишки: хронічну анальну тріщину і анальний поліп - у 18 (11\%) пацієнтів, хронічну анальну тріщину і комбінований геморой - у 14 (9\%), комбінований геморой і анальний поліп - у 11 (6,7\%), комбінований геморой і хронічний парапроктит - у 11 (6,7\%), хронічну анальну тріщину, анальний поліп і гіпертрофовані перианальні шкірні мітки - у 5 (3\%), комбінований геморой, хронічну анальну тріщину і анальний поліп - у 5 (3\%), зовнішній геморой і анальний поліп - у 4 (2,4\%).

Характер виконаних оперативних втручань залежав від варіанта ПП анального каналу та прямої кишки. Найчастіше виконували такі комбінації оперативних втручань: гемороїдектомія, висічення анальної тріщини - у 14 (9\%) пацієнтів, висічення анальної тріщини, поліпектомія - у 18 (11\%), гемороїдектомія, поліпектомія у 11 (6,7\%), гемороїдектомія, висічення анальної фістули - у 11 (6,7\%), висічення анальної тріщини, поліпектомія, електроексцизія гіпертрофованої перианальної шкірної мітки - у 5 (3\%), гемороїдектомія, висічення анальної тріщини, поліпектомія - у 5 (3\%), гемороїдектомія, поліпектомія - у 4 (2,4\%).

Проведене дослідження показало, що при використанні апарата ВЧEX “ERBE ICC 200" операція тривала в середньому $(20 \pm 5)$ хв, у контрольній групі - (30 \pm 5$)$ хв, об'єм крововтрати становив відповідно (15 \pm 5$)$ і (40 \pm 10) мл. Больовий синдром у післяопераційному періоді був більш виражений у пацієнтів контрольної групи, яким для знеболення потрібно було (4 \pm 1$)$ мл наркотичних засобів, тоді як пацієнтам досліджуваної групи - (2 $\pm 1)$ мл. Період лікування у стаціонарі у пацієнтів дослі-

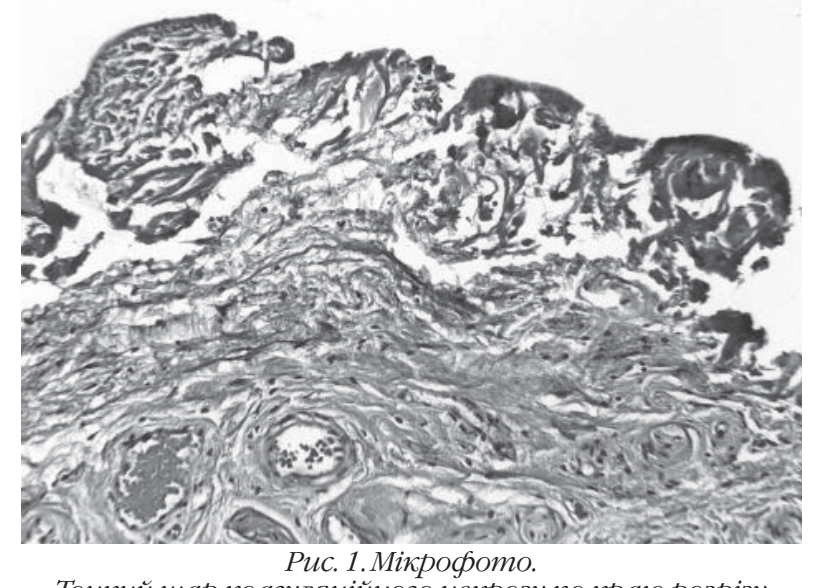

Тонкий шар коагуляційного некрозу по краюо розрізу після використання електрохірургічного методу. Забарвлення гематоксиліном та еозином. $36 . \times 100$.

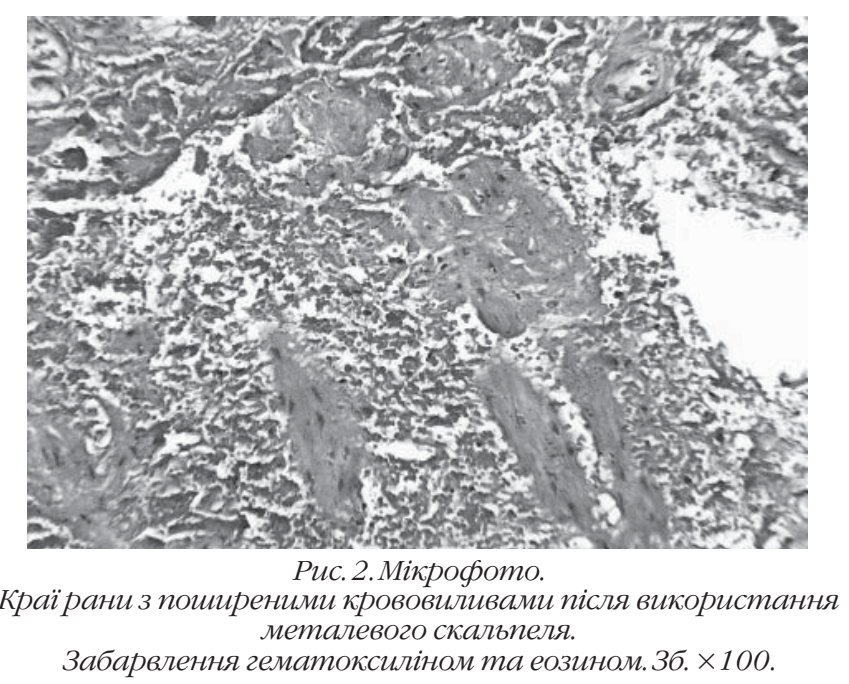


джуваної групи становив (5 \pm 1$)$ доба, контрольної групи - (7 \pm 1$)$ доба. У післяопераційному періоді у пацієнтів досліджуваної групи не виявлено ознак недостатності анального сфінктера, а також формування рубцевої стриктури анального каналу. У 4 (3,6\%) пацієнтів контрольної групи сформувалась рубцева стриктура анального каналу, яку лікували консервативно (у 2) та оперативно (у 2).

Морфологічним дослідженням встановлено, що під час розрізу тканин з використанням електрохірургічного методу відбувається їх розсічення і коагуляція з контролем гемостазу та утворенням тонкого шару коагуляційного некрозу товщиною в середньому $(0,286 \pm 0,15)$ мм (рuс. 1).

Використання хірургічного металевого скальпеля супроводжується певною механічною травматизацією і крововиливами в краях операційної рани, що в подальшому уповільнюе іiі загоєння (рис. 2).

\section{Обговорення}

У разі застосування апарата ВЧEX “ERBE ICC 200” для лікування хворих з ПП анального каналу і прямої кишки зменшується у півтора разу тривалість оперативних втручань, яка становила в середньому (20 \pm 5) хв. Суттєвою перевагою даної електрохірургічної технології у лікуванні цієї категорії пацієнтів було зменшення майже втричі об'єму крововтрати під час операції, який у досліджуваній групі становив у середньому $(15 \pm 5)$ мл.

Використання апарата ВЧЕX “ERBE ICC 200” супроводжувалось утворенням тонкого шару коагуляційного некрозу в тканинах глибиною в середньому $(0,286 \pm 0,15)$ мм, завдяки чому у пацієнтів досліджуваної групи майже вдвічі зменшувалась вираженість больового синдрому і вони потребували вдвічі менше наркотичних засобів для знеболення порівняно з контрольною групою. При застосуванні металевого хірургічного скальпеля утворювались поширені крововиливи у тканинах, що обумовлювало їх більшу травматизацію і відповідно більш виражений больовий синдром у пацієнтів контрольної групи.

Вплив на тканину при використанні методу ВЧЕХ був мінімальним, що сприяло формуванню косметич- ного післяопераційного рубця, запобігало виникненню рубцевих стриктур анального каналу та приводило до швидшого загоєння ран і більш швидкої реабілітації у пацієнтів досліджуваної групи.

\section{Висновки}

1. Застосування апарата ВЧEX “ERBE ICC 200” сприяе скороченню тривалості операції, майже втричі зменшує об'єм крововтрати під час ії виконання, суттєво знижує больовий синдром в післяопераційному періоді, скорочує терміни лікування пацієнтів, що обумовлює їх швидку медико-соціальну реабілітацію.

2. Мінімальна травматизація і контроль гемостазу при використанні такої хірургічної методики є беззаперечними перевагами перед використанням металевого скальпеля, оскільки забезпечує швидке загоєння рани з формуванням ніжного післяопераційного рубця, завдяки якому не виникають рубцеві стриктури та недостатність анального сфінктера в післяопераційному періоді.

\section{References}

1. Gavrilenko SP, Drevetnjak AA, Kostyrnoj AV. Metody operativnogo lechenija gemorroja v sochetanii s anal'noj treshhinoj. In: materialy II siezda koloproktologov stran SNG, III siezda koloproktologov Ukrainy s uchastiem stran Central'noj i Vostochnoj Evropy. Odessa; 2011:407-8. [In Russian].

2. Klein IW. Common anal problems. The medical clin North Am. 2014;98(3):609-20.

3. Borota AV, Hul'mamedov FI, Hul'mamedov VA, Polunin GE, Vasilenko LI, Gerasimenko EA. Rezul taty hirurgicheskogo lechenija sochetannoj neopuholevoj patologii anal'nogo kanala i prjamoj kishki. Koloproctologia. 2016;2(56):18-9. [In Russian].

4. Shin IP, Pavlenko VV, Ptakchin AV, Gzogjan AA. Rezul'taty odnomomentnyh operacij pri sochetannyh zabolevanijah anorektal'noj oblasti. In: materialy III vserossijskogo siezda koloproktologov. Belgorod; 2011:59.[In Russian].

5. Tjan LV, Turebaev DK, Osipov DP. Lechenie hronicheskogo paraproktita $\mathrm{v}$ sochetanii s hronicheskim gemorroem pri pomoshhi ul'trazvukovogo skal'pelja. In: materialy III vserossijskogo siezda koloproktologov. Belgorod;2011:53.[In Russian].

6. Dacenko AB, Bardjuk AJ, Sedak VV, Kirillov AV, Bogun EA. Taktika lechenija bol'nyh a oslozhnennymi anal'nymi treshhinami. In: materialy III vserossijskogo siezda koloproktologov. Belgorod; 2011:26. [In Russian]. 